\title{
Evaluation Of Curriculum At The Primary Level In Light Of Education Policies And Plans In Pakistan
}

\author{
Shahida Perveen, University of Education, Pakistan
}

\begin{abstract}
The paper is based on a research conducted to evaluate the curriculum at the primary level in the light of education policies and plans in Pakistan. The article discusses the objectives of the curriculum at the primary level and analyzes different education policies and plans regarding the achievements of objectives. Results revealed that the objectives of curriculum were not fully achieved. The procedure of the implementation of policies and plans regarding curriculum remained weak.
\end{abstract}

Keywords: Evaluation; Curriculum; Primary Level; Policies; Plans, Pakistan

\section{INTRODUCTION}

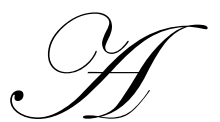

(1989), the curricu

curriculum includes overall educational activities which are aimed at achieving the objectives given in the education policies. Curriculum is developed to achieve these objectives. Without suitable curriculum, objectives of the education cannot be achieved. According to Govt. of Pakistan the text produced.

Education policies and curricula are formulated by the federal government and transferred to schools through provinces for implementation. Teachers are not involved in curriculum development and curriculum is imposed on the teachers for execution (Shah, 1992). Most of the teachers do not have an understanding of the national curriculum and misunderstand the textbooks (Khan, 2008). The teachers have not been able to impart basic skills, like reading and writing, which enable the students to express themselves well (Salahuddin, 2009). The content in the textbooks is persuasive enough to induce all the requisite skills suited to an esteemed society in the students. Unfortunately, the output does not meet the acclaimed standard of good qualities that can influence their practical life (Hussain 2000). The education sector was not given due priority in the past. Weak implementation and monitoring of programmes, low access to basic education and static curriculum, and poor quality of public education has impeded the development process in education (Govt. of Pakistan, 2006). Pakistan spends 2.2 percent of GNP on education. Successive allocations of the five-year financial plan have always been less than what is needed.

A policy could only be a success when the existing shortfalls are addressed with a strong footing of appropriate pursuance to match with the resources and when viable methods for implementing the policies at a consistent follow-up rate are sought. In Pakistan, various policies came up that emphasized primary education curriculum, but until now, much more is needed to be done. The curriculum is to be made more functional and of everyday use, the quality of curriculum is to be improved by improving the allied factors, and the financial allocations and their proper utilization needs special care and attention. How far the policies and plans could be a success is a matter to ponder. Hence, the study was undertaken. The major purpose of the study was to evaluate the curriculum at the primary level in light of education policies and plans in Pakistan since 1947. 


\section{REVIEW OF LITERATURE}

\section{Proceedings of the Pakistan Education Conference (1947)}

Soon after independence in 1947, an All Education Conference was convened. According to the Govt. of Pakistan (1947), the committee agreed on the provision of Islamic conception-based education and proper integration of spiritual, social and vocational elements in education and suggested that English should be retained as a compulsory language at school stage with the medium of instruction to be left to each province to decide according to its requirements. The first five-year plan (1955-1960) focused on need-based curriculum, encouragement of creativity through arts and crafts and recreation, and appointment of curriculum experts to prepare learning materials (Govt. of Pakistan, 1956).

\section{Report of the Commission on National Education (1959)}

The commission recommended that curriculum should be adapted to the mental abilities of the children and related to everyday life. It must be so designed as to develop the basic skills in reading, writing and arithmetic, a liking for working with one's own hands, and a high sense of patriotism. Religious education should be a compulsory subject. Due emphasis should be placed on character building and teaching of the national language (Govt. of Pakistan, 1960a). The second five-year plan (1960-1965) emphasized on revising the curriculum, improving the content, and developing teaching materials (Govt. of Pakistan, 1960b). The third five-year plan (1965-1970) envisaged to improve the curricula, develop scientific thinking, introduce elementary agriculture and craft courses, and make the curriculum child-centered and research-based (Govt. of Pakistan, 1965).

The Govt. of Pakistan (1966) observed that the curriculum committee that was set up for implementation of the recommendations of the commission unfortunately did not frame any syllabi for class 1 to V. The Govt. of Pakistan (1970) analyzed that curriculum revision was never based on adequate research experimentation and evaluation.

\section{The New Education Policy (1970)}

The policy and the fourth five-year plan (1970-1975) remained unimplemented.

\section{The Education Policy (1972-1980)}

The policy objectives were to establish a curriculum centre, to design need-based curricula, to revise curricula to eliminate overloading, emphasize learning of concepts and skills, and encourage observation, exploration, experimentation, practical works, and creative expression. This task would be assigned to representative committees of specialists, practicing teachers, and curriculum research experts. Physical education was to be included as an integral part of the primary curricula (Govt. of Pakistan, 1972). The Govt. of Pakistan (1977a) noted that the schemes of study were finalized and revised curricula had been introduced. Govt. of Pakistan (1977b) observed that the quality of textbooks, both in content and presentation, was poor. The fifth five-year plan (19781983) analyzed that curricula had been revised and introduced in all classes. The plan aimed at the assessment and improvement of educational aids and books and made the provision of teaching kits, teaching aids and supply of 100 supplementary readers to every school (Govt. of Pakistan, 1978).

\section{National Education Policy and Implementation Programme (1979)}

The policy emphasized the review of curricula and textbooks to ensure that adequate content on Islam and Islamic ideology was included. The policy introduced integrated curricula in classes I and II and more value was given to practical work and creative activities. The textbook boards were reorganized to improve the quality of textbooks (Govt. of Pakistan, 1979). Policy made the provision of teaching kits and supplementary readers (Govt. of Pakistan, 1979). The Govt. of Pakistan (1980) noted that new curriculum had been introduced with emphasis on Islam and ideology of Pakistan. Islamiat had been made compulsory and Urdu had been made the medium of instruction. The Govt. of Pakistan (1981) observed that curriculum content had been strengthened for national 
cohesion and integration. Pakistan Studies had been introduced as a compulsory subject from class I. Govt. of Pakistan (1983b) introduced integrated curricula and published a new syllabus for class I.

The sixth five-year plan (1983-1988) observed that curriculum was mostly urban-oriented and was not relevant to the daily lives of the children. The curriculum was too demanding and, as such, failed to achieve the objectives. The plan proposed that during the first three years of schooling, only religious instruction, reading, writing and elementary arithmetic would be taught. Teaching of a full curriculum would begin with class IV (Govt. of Pakistan, 1983a). The Govt. of Pakistan (1986) observed that the curriculum was over-extended and rigid. The seventh five-year plan (1988-1993) emphasized the need-based and skill-oriented curriculum and to improve the quality of textbooks (Govt. of Pakistan, 1988).

\section{National Education Policy (1992)}

The policy was not implemented.

The Govt. of Pakistan (1992) observed that textbooks did not properly reflect the spirit and intentions of the school curricula. Those were generally of poor quality and contained materials that were unnecessarily repetitive. The language, in many cases, was defective as was the presentation of content, which were not in agreement with the comprehension level of the children. The eighth five-year plan (1993-1998) noted that the curricula and textbooks were unsatisfactory. The plan envisaged the qualitative improvement of curricula by making the courses demand-oriented and to encourage enquiry, creativity and analytical thinking (Govt. of Pakistan, 1993). The Govt. of Pakistan (1997) observed that new textbooks based on integrated curricula had been introduced in Punjab.

\section{The National Education Policy (1998-2010)}

The Govt. of Pakistan (1998a) observed that learning materials were inadequate and of poor quality. The policy made the provision of supplementary reading materials in schools. The policy objectives were: 1) the development of a new and demanding curricula, 2) focus on moral values, 3) uniform curricula for all public and private schools, 4) to include computer literacy, population and environmental education, health education, AIDs education, and value education in the curriculum, and 5) improve the quality of textbooks with lowering the cost.

The ninth five-year plan (1998-2003) analyzed that curricula were mostly non-relevant to the market requirements. The plan emphasized on the revision of curricula (Govt. of Pakistan, 1998b). The Govt. of Pakistan (1999) noted that instructional material on Islamic education, drugs, environment, population and international understanding was developed for inclusion in textbooks. The Govt. of Pakistan (2001) observed that curriculum had limited relevance to real life problems and hardly promoted creativity and innovations. Therefore, the curriculum was being revised. The Govt. of Pakistan (2002) analyzed that curricula were mostly non-relevant to the present day requirements. Curricula and textbooks of selected subjects, including mathematics, English, and social studies, for classes IV-V had been revised. The Govt. of Pakistan (2003a) observed that the curriculum was mostly urbanoriented. The Govt. of Pakistan (2003b) noted that there was a shortage of teaching materials. The Govt. of Pakistan (2005) stated that teaching English had been introduced. The Govt. of Pakistan (2006) stated that the English language had been made compulsory and that English was also introduced as a medium of instruction. It was decided to review the curriculum. The Govt. of Pakistan (2008) observed that the National Curriculum Counsel had prepared a comprehensive review of curriculum to make it relevant to the students' needs. The National Textbooks and Learning Materials Policy (2007) had been prepared to prop up the quality of textbooks.

\section{RESEARCH STUDIES}

Research studies indicated that curriculum was highly loaded and more demanding (Bhatti et al, 1986). It did not fulfill the needs and requirements of the students (Muhammad, 1988, Choudhary, 1992, Jatoi, 1995) and lacked relevance (Jalalzai, 2005). The course contents were highly structured and inflexible (Choudhary, 1989). The curriculum placed a premium on book knowledge and rote learning (Khawaja, 1985). The textbooks were thoughtlessly and unattractively prepared (Malik, 1987) and did not contain up-to-date knowledge. There was a significant difference between theory and practice in the field (Rehman, 1990). 
Khalid (1991) and Mirza (2003) concluded that curriculum documents were not provided to the teachers. Shah (1992) and Hussain (2000) observed that curricula were developed without the involvement of teachers. Mirza (2006) analyzed that there was a lack of funds, science equipment, and attractive reading materials.

\section{RESEARCH METHODOLOGY}

The population of the study consisted of 157,200 primary schools (112,800 boys and 44,400 girls), 450,100 teachers, 157,200 head teachers, 1,836 supervisory staff, and 310 administrators, along with 104 districts of four provinces. Twenty-five districts from all over Pakistan were randomly selected. From the sample institutions, 50 government primary schools ( 25 boys and 25 girls) were taken from each district and 1,250 heads (625 males and 625 females), 2,500 teachers (1,250 males and 1,250 females), 104 male supervisory staff and administrators, and 75 female supervisory staff and administrators were randomly selected. Three questionnaires were developed and personally administered to the teachers, heads, supervisory staff and administrators. Moreover, national education policies, development plans, other official documents, and research reports were analyzed. The analysis of data is presented in the following tables.

Table 1: Government Primary School Teachers (Male and Female) Opine that Primary School Curriculum is Difficult.

\begin{tabular}{|l|c|c|c|c|c|}
\hline \multicolumn{1}{|c|}{ Responses } & Mostly & To some extent & Not at all & Total & $\chi^{\mathbf{2}}$ \\
\hline Male & 412 & 597 & 241 & 1250 & $152.16^{*}$ \\
\hline Female & 372 & 518 & 360 & 1250 & $37.14^{*}$ \\
\hline
\end{tabular}

* Significant $\quad \mathrm{df}=2 \quad$ Table value of $\chi^{2}$ at .05 level $=5.99$

Table 1 shows that calculated value of $\chi^{2}$ was found to be significant at 0.05 level in both cases. The trend of responses (both male and female) was on 'to some extent'. Therefore, the statement, "Govt. primary school teachers (male and female) opine that primary school curriculum is difficult" is accepted in favour of the option "to some extent'.

Table 2: Government Primary School Heads (Male and Female) Opine that a Teaching Kit is Available.

\begin{tabular}{|l|c|c|c|c|c|}
\hline \multicolumn{1}{|c|}{ Responses } & Mostly & To some extent & Not at all & Total & $\chi^{2}$ \\
\hline Male & 91 & 141 & 393 & 625 & $251.50^{*}$ \\
\hline Female & 92 & 120 & 413 & 625 & $303.48^{*}$ \\
\hline
\end{tabular}

* Significant $\quad \mathrm{df}=2 \quad$ Table value of $\chi^{2}$ at .05 level $=5.99$

Table 2 shows the calculated value of $\chi^{2}$ was found to be significant at 0.05 level in both cases. The trend of responses of heads (both male and female) was on 'not at all'. Hence, the statement, "Govt. primary school heads (male and female) opine that a teaching kit is available" is negatively accepted.

Table 3: Government Primary School Supervisory Staff and Administrators (Male and Female) Opine that the Curriculum at the Primary Level needs Revision.

\begin{tabular}{|l|c|c|c|c|c|c|c|}
\hline Responses & SA & AG & UD & DA & SD & Total & $\chi^{2}$ \\
\hline Male & 18 & 72 & 6 & 8 & Nil & 104 & $100.60^{*}$ \\
\hline Female & 10 & 57 & Nil & 8 & Nil & 75 & $93.23^{*}$ \\
\hline
\end{tabular}

* Significant $\quad \mathrm{df}=4$ Table value of $\chi^{2}$ at 0.05 level $=9.49$

Legend: SA: Strongly Agreed AG: Agreed UD: Undecided DA: Disagreed SD: Strongly Disagreed

Table 3 indicates that calculated value of $\chi^{2}$ was found to be significant at 0.05 level in both cases. The trend of responses of supervisory staff and administrators (both male and female) was on 'agree'. Hence, the statement, "Govt. primary school supervisory staff and administrators (male and female) opine that the curriculum at the primary level needs revision" is accepted for both cases. 


\section{CONCLUSIONS}

In the light of analysis of the data and findings of the study, the following conclusions were drawn:

- $\quad$ Education policies deal with aims, goals and objectives of education. It was observed that education policies and plans were not implemented in letter and spirit and objectives of the curriculum were not fully achieved. The main objectives of the curriculum were need-based and skill-oriented curriculum related to everyday life, elimination of overloading, improvement of the quality of curricula and textbooks, provision of teaching kits and supplementary reading materials, and adoption of uniform curricula for all public and private schools. The objectives of skill-oriented curriculum, elimination of overloading, provision of teaching kits and supplementary reading materials, and the adoption of uniform curricula were not achieved.

- It was evident from the data and discussion that curriculum was urban-oriented and, to some extent, difficult. The revision of curricula was considered necessary. It was observed that curriculum was developing both Islamic and scientific thinking in the students. It was observed that prescribed syllabus of primary school students was lengthy, but it was completed on time during the session.

- It was evident that government primary school teachers and heads were not involved in curriculum development. Curriculum documents were not provided to them. In-service training was provided to the teachers, but training for revised curricula was not provided to them. English was taught as a compulsory subject in all government primary schools, but English teachers were not available to them, except in some areas of the Punjab.

- $\quad$ A teaching kit helps the learner develop the potential of observation, exploration and understanding. It was found that the majority of schools had no teaching kits. Supplementary reading materials help the learner to increase vocabulary and vision. It was evident from the data and discussion that supplementary reading materials were not available in most of the schools. Sports and games are an integral part of education and important for the development of the learner. It was concluded that the majority of government primary schools had no sports equipment and most of the teachers did not arrange sports competitions in school, but they arranged other co-curricular activities.

\section{DISCUSSION}

Curriculum is prepared to achieve the policy's objectives. It was observed that objectives of the curriculum were not fully achieved, which might be due to non-implementation of the policies. The Govt. of Pakistan (1998a, 2006) observed that there was a weak and defective implementation mechanism.

The curriculum was urban-oriented and, to some extent, difficult. The students in rural areas found the curriculum difficult to understand. Upon discussion with the teachers, they pointed out that the curricula of English and Science were found to be very difficult. Primary school teachers did not follow the terminologies of science as it was written in English. Moreover, some concepts in science were presented in such a way that it was not possible for the students to comprehend, which might be due to the difference between theory and practice. Rehman (1990) held the same opinion that there was a significant difference between the theory and practice in the field. Curriculum was developing both Islamic and scientific thinking in students. Although the quality of textbooks was improved with lowering the cost, many mistakes were still found, both in content and presentation.

The teacher is the main source of implementation of curricula and character building. It was evident that government primary school teachers, as well as heads, were not involved in curriculum development, which might be due to the lack of interest. Muhammad (1988), Shah (1992), and Hussain (2000) observed that teachers were not involved in curriculum development.

There is a link between access to learning materials and the quality of education. Education standards in many government primary schools were adversely affected by poor provision of learning resource materials. The majority of the schools had no teaching kits at all. Govt. of Pakistan (1998a, 2000) held the same opinion that learning materials were inadequate and of poor quality. 
Every student must have sufficient reading skills. Development of reading habits is necessary for the students and can be developed by the use of supplementary reading materials. In general, there was found to be a lack of supplementary reading materials. If by chance rare books were available in any school, they were mostly out of the reach of the students, even though the Govt. of Pakistan (1978a, 1998a) assured the provision and use of supplementary reading materials.

Education policies and plans were formulated from time to time and objectives of the curriculum were well reflected, but the implementation remained a shortcoming. Objectives given in the policies were over ambitious and procedure of implementation revealed serious limitations, such as lack of participation of teachers and heads during the development phase, lack of training regarding revised curricula, overloaded implementation machinery, centralization in decision-making, lack of finance, and lack of political commitment.

\section{NOTES}

Curriculum at the primary level in Pakistan generally includes Reading, Writing Urdu, Mathematics, Science, Social Studies, Islamic Studies and Nazira Quran.

\section{AUTHOR INFORMATION}

Dr. Shahida Perveen is an assistant professor at University of Education, Jauharabad Campus, District Khushab, Punjab. She is senior vice president of Academic Staff Association, University of Education, Lahore. She has been serving as chairperson, president, vice president and member of various community development organizations since 1983. She has presented many papers in seminars and delivered lectures as resource person. Her area of interest is education policies and plans of Pakistan. She has got many best achievement awards from government and non-government organizations.

\section{REFERENCES}

1. Bhatti et al. 1986. Primary Education Improvement: Desired Measures. Educational Development Series I. National Education Council, Islamabad. 98p.

2. Choudhary, E. 1989. Institutionalization of Basic Education. Planning of Basic Education in Pakistan. Academy of Education Planning and Management. Ministry of Education, Islamabad. 124p.

3. Choudhary, M. I. 2003. The Role of Teachers in Uplift of Education (II). In: Daily The News International. $3^{\text {rd }}$ September, 2003. Lahore.

4. Choudhary, R. 1992. Importance and Need of Literacy and Basic Education for National Development. Literacy in Pakistan. In: Literacy and Basic Education in Pakistan (Report of the Seminar). National Education and Training Commission in Collaboration with UNICEF, Islamabad. 59p.

5. Govt. of Pakistan.1947.Proceeding of Pakistan Education Conference. Ministry of Interior. Education Division, Karachi. pp 20-22.

6. Govt. of Pakistan. 1956. The First Five Year Plan.1955-60.Planning Board, Karachi. pp 397-398.

7. Govt. of Pakistan.1960a. Report of the Commission on National Education. Ministry of Education, Karachi. pp.173-176.

8. Govt. of Pakistan.1960b.The Second Five Year Plan. 1960-65. Planning Commission, Karachi. pp.342

9. Govt. of Pakistan.1965. The Third Five Year Plan. 1965-70. Planning Commission, Karachi.pp.188-191.

10. Govt. of Pakistan.1966. Report of the Commission on Student Problems and Welfare. Ministry of Education, Govt. of Pakistan Press, Karachi. 25p

11. Govt. of Pakistan.1970. The Fourth Five Year Plan.1970-75. Planning Commission, Karachi. 168p.

12. Govt. of Pakistan.1972. The Education Policy. 1972-80. Ministry of Education, Islamabad. 27p.

13. Govt. of Pakistan.1977a. Pakistan Economic Survey 1976-77. Finance Division, Economic Adviser's Wing, Islamabad. pp 202-210

14. Govt. of Pakistan.1977b. National Education Conference October 3-5, 1977. Ministry of Education. Islamabad. $41 \mathrm{p}$

15. Govt. of Pakistan. 1978. The Fifth Five Year Plan. 1978 -83. Planning Commission, Karachi. pp 297-309. 
16. Govt. of Pakistan. 1979. National Education Policy and Implementation Programme, Ministry of Education, Islamabad. pp 56-57.

17. Govt. of Pakistan. 1980. Pakistan Economic Survey 1979-80. Finance Division, Economic Adviser's Wing, Islamabad. pp 197-202

18. Govt. of Pakistan. 1981. Pakistan Economic Survey 1980-81. Finance Division, Economic Adviser's Wing, Islamabad. pp 200-205

19. Govt. of Pakistan.1983a. The Sixth Five Year Plan. 1983-88. Planning Commission. Islamabad. pp 383392

20. Govt. of Pakistan. 1983b. Pakistan Economic Survey 1982-83. Finance Division, Economic Adviser's Wing, Islamabad. pp 181-184

21. Govt. of Pakistan. 1986. Pakistan Economic Survey 1985-86. Finance Division, Economic Adviser's Wing, Islamabad. $18 \mathrm{p}$

22. Govt. of Pakistan. 1988. The Seventh Five Year Plan.1988-93. Planning Commission. Islamabad .pp. 246247.

23. Govt. of Pakistan. 1989. National Education Conference, Working Papers. Ministry of Education, Islamabad. 56p

24. Govt. of Pakistan. 1992. National Education Policy. Ministry of Education, Islamabad. 23p.

25. Govt. of Pakistan. 1993. The Eighth Five Year plan. 1993-98. Planning Commission, Islamabad. 316p.

26. Govt. of Pakistan. 1997. Economic Survey of Pakistan 1996-1997. Economic Adviser's Wing. Finance Division, Islamabad. $119 \mathrm{p}$.

27. Govt. of Pakistan. 1998a. National Education Policy. 1998-2010. Ministry of Education, Islamabad. pp. 2732.

28. Govt. of Pakistan. 1998b. The Ninth Five Year Plan. 19988-2003. Planning Commission, Islamabad. pp.410

29. Govt. of Pakistan. 1999. Economic Survey 1998-99. Finance Division, Economic Adviser's Wing, Islamabad. 117p.

30. Govt. of Pakistan. 2000. Economic Survey 1999-2000. Finance Division, Economic Adviser’s Wing, Islamabad. 140p.

31. Govt. of Pakistan. 2001. Economic Survey 2000-01. Finance Division, Economic Adviser's Wing, Islamabad.. 157p.

32. Govt. of Pakistan. 2002. Pakistan Economic Survey 2001-02. Finance Division, Economic Adviser's Wing, Islamabad. 152p.

33. Govt. of Pakistan. 2003a. National Plan of Action on Education for All (2001-2015) Pakistan. Ministry of Education Islamabad in collaboration with UNESCO April 2003. Ministry of Education, Islamabad. 14p

34. Govt. of Pakistan. 2003b. Economic Survey of Pakistan. 2002-03. Finance Division, Economic Adviser's Wing, Islamabad. 159p

35. Govt. of Pakistan. 2005. Pakistan Economic Survey 2004-05. Finance Division, Economic Adviser's Wing. Islamabad. $137 \mathrm{p}$.

36. Govt. of Pakistan. 2006. Pakistan Economic Survey 2005-06. Finance Division, Economic Adviser's Wing. Islamabad. $175 \mathrm{p}$.

37. Govt. of Pakistan. 2008. Pakistan Economic Survey 2007-08. Finance Division, Economic Adviser's Wing. Islamabad. pp 177-178

38. Hussain, S. 2000. A Study to Compare the Elementary Education Curricula of Government and Privately Managed Institutions. Unpublished M. Phil Thesis, University of Arid Agriculture. Rawalpindi. 140p

39. Jalalzai, M.K. 2005. The Crisis of Education in Pakistan, State, Education and the Textbooks. Al-Abbas International, Lahore. 26p

40. Jatoi, H. 1995. Brief Review of Educational Policies and Five Year Development Plans 1947-92. Unpublished. Academy of Education Planning and Management, Ministry of Education, Islamabad. 8p.

41. Khalid, S.A. 1991. Primary Taleem. Subai Taleemi Council, Balochistan. Quetta Printing Press, Quetta. $246 \mathrm{p}$

42. Khan, B. 2008. Dilemma of Pakistani School Teachers. In: Daily The News International. 23 ${ }^{\text {rd }}$ March, 2008, Lahore

43. Khawaja, 1985. A Conceptual Paper on New Developments in Primary Education in Pakistan. Academy of Educational Planning and Management. Ministry of Education. Islamabad. 18p 
44. Malik, I. I. 1987. Education of Women in Pakistan. Pakistan Education Journal. The Central Bureau of Education. Ministry of Education, Islamabad. 2(I): 57.

45. Mirza, A. 2006. Course Change. In: Daily The News International. 19th February, 2006, Lahore.

46. Mirza, M. 2003. Quality of Primary Education in Pakistan. Ministry of Education, Govt. of Pakistan in collaboration with UNESCO, Islamabad. pp 13-15.

47. Muhammad, M.G. 1988. Pakistan main Primary Taleem (Tehqiqi-o-Tajziati Mutalia). Beacon Books. Multan. 238p

48. Rehman, S. 1990. Seventh Workshop on Educational Planning and Management for District Education Officers October 22-31, 1988. Academy of Educational Planning and Management, Islamabad. 21p.

49. Salahuddin, S. 2009. No Short Cuts Here. In: Daily The News International. 9th March, 2009, Lahore.

50. Shah, M. 1992. Staff Development for Teachers in Pakistan. Unpublished M.A. Thesis. School of Education. University of Bristol, Bristol.43p 